\title{
Performance analysis of regional AquaCrop (v6.1) biomass and surface soil moisture simulations using satellite and in situ observations
}

\author{
Shannon de Roos ${ }^{1}$, Gabriëlle J. M. De Lannoy ${ }^{1}$, Dirk Raes ${ }^{1}$ \\ ${ }^{1}$ Department of Earth and Environmental Sciences, KU Leuven, Heverlee, B-3001, Belgium \\ Correspondence to: Shannon de Roos (Shannon.deroos@kuleuven.be)
}

\begin{abstract}
The current intensive use of agricultural land is affecting the land quality and contributes to climate change. Feeding the world's growing population under changing climatic conditions demands a global transition to more sustainable agricultural systems. This requires good insight in land cultivation practices at the field to global scale.

This study outlines a spatially distributed version of the field-scale crop model AquaCrop version 6.1, to simulate agricultural

5 biomass production and soil moisture variability over Europe at a relatively fine resolution of $30 \operatorname{arcseconds}(\sim 1 \mathrm{~km})$. A highly efficient parallel processing system is implemented to run the model regionally with global meteorological input data from the Modern-Era Retrospective analysis for Research and Applications, version 2 (MERRA-2), soil textural information from the Harmonized World Soil Database, version 1.2 (HWSDv1.2), and generic crop information. Daily crop biomass production is evaluated with the Copernicus Global Land Service dry matter productivity (CGLS-DMP) data. Surface soil moisture is 10 compared against NASA Soil Moisture Active Passive surface soil moisture (SMAP-SSM) retrievals, the Copernicus Global Land Service surface soil moisture (CGLS-SSM) product derived from Sentinel-1, and in situ data from the International Soil Moisture Network (ISMN). Over central Europe, the regional AquaCrop model is able to capture the temporal variability in both biomass production and soil moisture, with a spatial mean correlation of 0.8 (CGLS-DMP), 0.74 (SMAP-SSM) and 0.52 (CGLS-SSM), respectively. The higher performance when evaluating with SMAP-SSM compared to Sentinel-1 CGLS-SSM

15 is largely due to the lower quality of CGLS-SSM satellite retrievals under growing vegetation. The regional model further captures the interannual variability, with a mean anomaly correlation of 0.46 for daily biomass, and mean anomaly correlations of 0.65 (SMAP-SSM) and 0.50 (CGLS-SSM) for soil moisture. It is shown that soil textural characteristics and irrigated areas influence the model performance. Overall, the regional AquaCrop model proves to be useful in assessing crop production and soil moisture at various scales and could serve as a bridge between point-based and global models.
\end{abstract}


https://doi.org/10.5194/gmd-2021-98

Preprint. Discussion started: 17 May 2021

(c) Author(s) 2021. CC BY 4.0 License.

\section{Introduction}

Over the past 60 years, global agricultural production has more than tripled (FAO, 2017). This became possible through productivity-enhanced technologies, industrialization and expansion of agricultural land. However, the current intensive use of cropland is resulting in reduced land quality and increased greenhouse gas emissions, which in turn impact agricultural systems (Foley et al., 2011; Kopittke et al., 2019). To meet the future crop demand of a vastly growing population, while minimizing the ecological footprint and increasing the crop resilience for changing climatic conditions, the need to adapt to more effective and sustainable land cultivation practices is urgent (Aznar-Sánchez et al., 2019; Pingali, 2012; Raes and Vanuytrecht, 2017).

To evaluate the effect of environmental conditions and different management practices on crop production, there exists a variety of models that simulate the biophysiological growth of crops at the field scale. An overview of 70 of such crop models

30 is given by Di Paola et al. (2016). Some of these point-based crop models have more recently been upscaled and assessed at a regional to global level (Balkovic et al., 2013, Boogaard et al., 2013, De Wit and van Diepen, 2007, Liu et al., 2007, Müller et al., 2018, Nichols et al., 2011, Resop et al., 2012, Roerink et al., 2012, Stöckle et al., 2014). Large-scale crop models are a valuable asset in providing information to policy makers and for applications in climate scenario analyses (Asseng et al., 2013, Iizumi et al., 2018). A downside of upscaled crop models, especially at the global scale, is that they often suffer from the

35 generalization of input data, resulting in a higher bias and loss of information at smaller scales. Some studies have attempted to reduce such errors by assimilating satellite observations in a crop modelling system (Mladenova et al., 2019). The AgMIP Global Gridded Model Intercomparisons (GGCMI) is a framework initiated to overcome this issue. It is built on a large group of crop modelling researchers that combine and intercompare a set of upscaled point models or global gridded crop models to assess and reduce the bias and uncertainties at a global level (Müller et al., 2017). However, the transitions between plant,

40 field, and regional scales in agricultural modelling remains a challenge, and more insight is needed in agricultural crop responses at various spatial and temporal scales with different levels of agricultural practices. To this end, a high-resolution regional crop model can serve as a bridge between the point and global level, combining information from various scales.

This study presents a methodology to apply the field-scale AquaCrop model efficiently over a large region at any spatial resolution. AquaCrop was developed by the FAO to estimate responses of herbaceous crops to water (Raes et al., 2009; Steduto,

45 et al., 2009). It differs from most other crop models by its low requirement of detailed input data, as it aims for a balance between simplicity, accuracy and robustness (Steduto, et al., 2009). The model has been applied in numerous studies for various crop types and environmental conditions and shows good results in simulating crop biomass and yield, especially when calibrated for local field conditions (Abedinpour et al., 2012; Geerts et al., 2009; Maniruzzaman et al., 2015; Razzaghi et al., 2017; Sandhu and Irmak, 2019). Earlier spatially distributed versions of AquaCrop were developed by e.g. Lorite et al. (2013),

50 Sallah et al. (2019) and Huang et al. (2019), using a Geographic Information System or batch processing with remote sensing data input. Some challenges of existing distributed AquaCrop systems are related to the limited scalability and high computational cost when they are applied to any large domain at any resolution, the difficulty to adapt to new AquaCrop model 
versions, the limitations in the upscaling of crop parameters from the plant or field to the grid scale (Han et al., 2020), or the availability of other suitable spatially distributed parameters or input information. Applications of the AquaCrop model at a continental scale exist, but are very limited (Dale et al., 2017) and so far are only used in combination with coarse spatial resolutions. To our best knowledge, no study has yet reported on high-resolution and large-scale (beyond country level) applications of AquaCrop.

The main objective of this research is to assess whether a high-resolution regional AquaCrop model can capture seasonal, inter-annual and short-term temporal variability, as well as the spatial variability, of biomass and soil moisture, when using global spatially distributed input data about soil texture and meteorology and assuming a generic crop. The model performance will be evaluated over Europe at a spatial resolution of $30 \operatorname{arcseconds}\left(1 / 120^{\circ}, \sim 1 \mathrm{~km}\right.$ at the equator), using satellite products derived from both optical and microwave sensors and in situ measurements.

The structure of the paper will be as follows: sections 2 and 3 will cover the methodology, with a description of the regional AquaCrop model, the evaluation datasets and performance metrics. In section 4 the results will be presented and discussed, followed by a conclusion in section 5 .

\section{The regional gridded AquaCrop model}

\subsection{AquaCrop}

AquaCrop is a daily crop-water productivity model that translates, on a daily basis, the simulated amount of crop transpiration into a proportional amount of biomass (Raes et al., 2009, Steduto et al., 2009). The relation between transpiration and biomass production is defined by a Water Productivity (WP) factor:

$$
\mathrm{B}=W P^{*} \sum \frac{T r}{E T_{o}}
$$

$\mathrm{B}\left(\right.$ ton ha $\left.\mathrm{a}^{-1}\right)$ is the cumulative biomass produced, $\mathrm{WP} *$ is the WP $\left(\mathrm{g} \mathrm{m}^{-2}\right)$ factor normalized for atmospheric $\mathrm{CO}_{2}(369.41 \mathrm{ppm}$ for the year 2000) and for climate, and $\operatorname{Tr}\left(\mathrm{mm} \mathrm{day}^{-1}\right)$ is the transpiration, also normalized for climate after division by the reference evapotranspiration, $\mathrm{ET}_{0}\left(\mathrm{~mm}_{\text {day }}{ }^{-1}\right)$. Because of this normalization, the $\mathrm{WP}^{*}$ factor only significantly differs between

$75 \mathrm{C} 3$ and $\mathrm{C} 4$ crops, where $\mathrm{C} 4$ crops have a higher WP* due to a more efficient carbon assimilation process. The calculation of $\mathrm{Tr}$ is dependent on $\mathrm{ET}_{0}$, the adjusted green canopy cover $\left(\mathrm{CC}^{*} ;-\right)$, the crop transpiration coefficient $\left(\mathrm{K}_{\mathrm{c}, \mathrm{tr}} ;-\right)$ and the soil water stress coefficient $\left(\mathrm{K}_{\mathrm{s}} ;-\right)$.

$$
\operatorname{Tr}=K_{S}\left(K_{c, t r} \cdot C C^{*}\right) \cdot E T_{0}
$$

In AquaCrop, the water reservoir in the root zone is balanced by ingoing fluxes of precipitation (minus runoff) and potentially

80 irrigation and capillary rise, and outgoing fluxes of evaporation and deep percolation. To calculate the soil water balance, AquaCrop divides the soil profile into multiple compartments over the total soil layer. Downward flow over these 
compartments is described by an exponential drainage function based on the volumetric water content in the compartment $\mathrm{i}$ $\left(\theta_{\mathrm{i}}\right)$ within the soil layer and drainage characteristics of the soil layer (Raes et al., 2006, Raes et al., 2009):

$$
\frac{\Delta \theta_{\mathrm{i}}}{\Delta \mathrm{t}}=\tau_{i}\left(\theta_{s a t}-\theta_{F C}\right) \frac{e^{\theta_{\mathrm{i}}-\theta_{\mathrm{FC}}-1}}{e^{\theta_{\mathrm{Sat}}-\theta_{\mathrm{FC}-1}}}
$$

$85 \Delta \theta_{\mathrm{i}} / \Delta \mathrm{t}$ is the decrease in water content over time $\left(\mathrm{m}^{3} \mathrm{~m}^{-3} \mathrm{~d}^{-1}\right), \theta_{\mathrm{FC}}$ and $\theta_{\text {sat }}$, are the volumetric moisture content at field capacity and at saturation (i.e. the porosity) of the soil layer, and $\tau_{\mathrm{i}}$ is the drainage coefficient derived from the saturated hydraulic conductivity $\left(\mathrm{K}_{\text {sat }}\right)$. Upward flow by capillary rise is estimated based on the depth of the groundwater table and hydraulic characteristics of the soil layers. Since no groundwater table is implemented in the regional version of the model in this paper, capillary rise is not included in the simulations. Soil evaporation is based on the soil wetness and crop cover (Ritchie, 1972) and water extraction by roots is described with the sink term from Feddes (1982). Because the root density for most crops is highest near the soil surface and decreases with increasing soil depth, the water extraction pattern by roots is simulated as follows: $40 / 30 / 20 / 10 \%$ for the upper quarter to the lowest quarter of the root zone (Raes et al., 2009). The estimated water retained in the root zone that will be available to the plants (Wr) at each daily timestep is described by the fraction of total available water (TAW) after subtraction of depleted water (Dr). TAW is the difference of volumetric moisture content between field capacity $\left(\theta_{\mathrm{FC}}\right)$ and wilting point $\left(\theta_{\mathrm{WP}}\right)$ over the root zone and is therefore dependent on soil texture and depth.

Plant stresses, such as water excess or water limitation, cold/heat air temperature stress, soil fertility and salinity stresses, can affect biomass production during different steps of the calculation procedure, depending on the process that is affected (i.e. canopy expansion, crop transpiration, pollination). The inclusion of stress factors is done by assigning unique thresholds to each of these biological processes (Raes et al., 2018).

\subsection{Regional model structure}

For the regional AquaCrop model, the simulation unit of a single field was replaced by a 30 arcsecond $(\sim 1-\mathrm{km})$ resolution pixel, and input and output were defined independently for each pixel. The system can easily be set up for any given resolution over any domain. The AquaCrop input data are categorized into several components e.g. climate, soil, vegetation and management. For each component, parameters are described in a text-file with a specific file extension that is recognized by the model. A Project Management (PRM) file oversees all the information for a single field (or pixel) and contains paths and names of these input files. This PRM-file is read and executed by AquaCrop, after which an output file is created.

The original Delphi source code of AquaCrop v6.1 was minimally adjusted and compiled on the Linux-based HighPerformance Computer (HPC) of the Vlaams Computer Centrum (VSC), and the resulting executable was plugged into a Python wrapper to allow massively parallel simulations to optimize the model efficiency over larger spatial domains. The current system allows for easy implementations of later versions of AquaCrop. The regional input files for the climate and soil are prepared before model execution. The Python wrapper then creates the PRM-file for a pixel as a first step of the model run, after which the AquaCrop model is executed and time series output is stored into a new folder for each pixel. The reason for creating the PRM-files right before the model execution is so that changes to a project can be made quickly. With this set 
https://doi.org/10.5194/gmd-2021-98

Preprint. Discussion started: 17 May 2021

(c) Author(s) 2021. CC BY 4.0 License.

(c) (i)

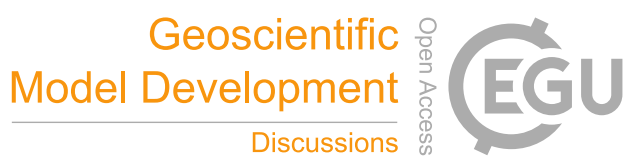

up, AquaCrop simulations over 1000 pixels for 8 years can be completed in 2.2 minutes wall time when using 36 processors.

115 The runs over the domain and period used in this study were completed in approximately 20 hours on 36 processors.

\subsection{Model input}

The meteorological forcings were extracted from the global Modern-Era Retrospective analysis for Research and Applications, version 2 (MERRA-2; Gelaro et al., 2017). The MERRA-2 meteorological variables have a 3-hourly temporal resolution and a spatial resolution of $0.5^{\circ}$ lat $\mathrm{x} 0.625^{\circ} \mathrm{lon}$. A nearest neighbour function was used to identify the 30 arcsecond pixels situated within one MERRA-2 grid to assign meteorological input. Minimum and maximum temperature and precipitation were converted into daily data needed for the AquaCrop model. The reference evapotranspiration $\mathrm{ET}_{0}$ was derived from the FAO Penman-Monteith equation, using radiation, wind speed, average temperature and dew temperature from MERRA-2 (Allen et al., 1998). For the FAO Penman-Monteith equation, a psychrometric constant of 0.067 was assumed for the entire domain and variations in topographic elevation were not taken into account. At high elevations ( $>1 \mathrm{~km}$ asl) this could result in deviations of $\mathrm{ET}_{0}$ of max $0.2 \mathrm{~mm} \mathrm{day}^{-1}$. However, since most agricultural areas are located at much lower elevations, the effect of the psychrometric constant was assumed to be very small. The long record of mean annual $\mathrm{CO}_{2}$ concentration observed at Mauna Loa (Hawai, USA) was used as $\mathrm{CO}_{2}$ input (default file in the database of AquaCrop).

The soil texture and organic matter was taken from the Harmonized World Soil Database version 1.2 (HWSDv1.2). The HWSDv1.2 has a spatial resolution of 30 arcseconds. The hydraulic soil properties for 253 different soil classes were linked to the information on mineral soil texture and organic matter from the HWSDv1.2 via pedo-transfer functions as in De Lannoy et al. (2014). More specifically, AquaCrop uses the soil water content at wilting point $\left(\theta_{\mathrm{WP}}\right)$, field capacity $\left(\theta_{\mathrm{FC}}\right)$ and saturation $\left(\theta_{\text {sat }}\right)$, and the saturated hydraulic conductivity $\left(\mathrm{K}_{\text {sat }}\right)$. These parameters are available for a top layer $(0-30 \mathrm{~cm})$ and a deeper layer $(30-100 \mathrm{~cm})$. The total soil depth available for root development is taken from the 1-km resolution root-zone depth map of the European Soil Data Centre (ESDAC) (Hiederer, 2013). In case the root-zone depth was less than or equal to $30 \mathrm{~cm}$, only the top layer parameters were considered. The soil properties of the deeper layer were included when the root-zone depth was deeper than $30 \mathrm{~cm}$. Stoniness and soil salinity were not considered. The modelled soil moisture was initialized at $\theta_{\mathrm{FC}}$ on January $1^{\text {st }}$ (winter in Europe) for all simulations.

A soil fertility stress parameter in the field management file provides an indication of the overall soil quality. The default of this parameter is $0 \%$, referencing to unlimited soil fertility. Since this situation is very rare in real fields, even for wellmaintained land, the value was set to $30 \%$ after initial model evaluation. With this reduction in soil fertility, a good to moderate crop production over the entire domain can be simulated in absence of water stress.

A single crop file was created to simulate crop production over Europe. Since the focus of this research is on biomass and not on yield, a single generic reference crop was parameterized. Spatial and temporal gaps of information at the $\sim 1-\mathrm{km}$ resolution prevent the inclusion of a more detailed crop parameterization, and the results will confirm the adequacy of the generic crop file. This file was minimally tuned after visual model evaluation and quantitative comparisons against satellite-based dry matter productivity (DMP, see below; Smets et al., 2019). The generic reference crop was developed to simulate annual biomass 
development of $\mathrm{C} 3$ crops, which are predominantly found in temperate climates, as opposed to $\mathrm{C} 4$ crops that are more common in hot and dry climatological zones (Monfreda et al., 2008, Still et al., 2003). The crop was simulated as a transplant, assuming a small presence of vegetation even during winter, and with an annual cycle of 365 days, starting on the first of January. Because of this fixed cycle, the canopy development had to be simulated in calendar days. This results in an error in the simulation of canopy expansion during cold periods, but due to the consideration of growing degrees in the simulation of crop transpiration, the reduced biomass production in these periods is still captured. The generic crop file is mostly suitable to simulate canopy development during the spring and summer season. The main crop parameters are presented in table 1.

The model was exclusively run for dominantly rainfed areas, based on the land use map of the CORINE Land Cover inventory 155 (Büttner, 2014) for the year 2012. This dataset is available at 100-m resolution and was aggregated to 30 arcseconds. If 50 or more classes within the aggregated pixel were identified as non-irrigated agriculture, the pixel was included for the regional AquaCrop model simulations.

Table 1 Main crop parameters of generic crop to simulate biomass over Europe

\begin{tabular}{ll}
\hline Generic crop main parameters & Input \\
\hline Crop type & leafy vegetable crop \\
Crop is sown/crop is transplanted & crop is transplanted \\
Determination of crop cycle & calendar days \\
Coefficient for maximum crop transpiration $\left(\mathrm{K}_{\mathrm{cTr}, \mathrm{x}} ;-\right)$ & 1.10 \\
Base temperature $\left({ }^{\circ} \mathrm{C}\right)$ below which crop development does not progress & 8.0 \\
Upper temperature $\left({ }^{\circ} \mathrm{C}\right)$ above which crop development no longer increases with & 30.0 \\
increase in temperature & \\
Minimum effective rooting depth (m) & 0.3 \\
Maximum effective rooting depth (m) & 1.0 \\
Normalized Water Productivity factor $\left(\mathrm{WP} * ;\right.$ g m $\left.{ }^{-2}\right)$ & 17.0 \\
Calendar days from transplanting to recovered transplant & 0 \\
Calendar days from transplanting to maximum rooting depth & 80 \\
Calendar days from transplanting to start senescence & 232 \\
Calendar days from transplanting to maturity & 365 \\
Calendar days from transplanting to flowering & 0 \\
Minimum growing degrees required for full crop transpiration $\left({ }^{\circ} \mathrm{C}-\right.$ day) & 10.0 \\
\hline
\end{tabular}


https://doi.org/10.5194/gmd-2021-98

Preprint. Discussion started: 17 May 2021

(c) Author(s) 2021. CC BY 4.0 License.

\section{Evaluation datasets and metrics}

\subsection{CGLS - DMP}

To evaluate simulations of daily biomass production, the $\sim 1-\mathrm{km}$ dry matter productivity product from the Copernicus Global Land Service (CGLS-DMP; $\mathrm{kg} \mathrm{ha}^{-1} \mathrm{day}^{-1}$ ) was used (Smets et al., 2019). The CGLS-DMP is based on a simplified Monteith

165 (1972) approach that makes use of the fraction of absorbed photosynthetically active radiation (fAPAR), which is derived from the optical satellite missions Satellite Pour l'Observation de la Terre (SPOT; 1999-2014) and Project for On-Board Autonomy - Vegetation (PROBA-V; 2014-present). The CGLS-DMP data are provided in 10-daily time steps, where each value is representative of the past 10 days for the years 1999 up to present date. To compare the data with the AquaCrop biomass, the nearest-neighbour function was used to spatially match the gridded simulations to the grid of CGLS-DMP and the median of

170 the modelled daily biomass production was computed for the corresponding 10-daily intervals of the CGLS-DMP products. Since the crop parameterization in AquaCrop is suited to simulate for the main growing season, the months November up to February were not included for the biomass evaluation.

\subsection{CGLS - SSM}

AquaCrop surface moisture content, i.e. the output of soil moisture in the top compartment of the soil profile, was evaluated

175 with a second CGLS product, i.e. the relative surface soil moisture (CGLS-SSM). CGLS-SSM provides data for the top few centimetres of the soil, available at the same $\sim 1-\mathrm{km}$ resolution as CGLS-DMP. This product is derived from the C-band radar onboard Sentinel-1, processed by the TU Wien (Bauer-Marschallinger et al., 2018), and available from October 2014 onwards. Processing steps included geo-correction, radiometric calibration and normalization of the incidence angle. No correction was included for dynamics in vegetation or surface roughness. The data are provided as relative soil moisture estimates (\%), that

180 have to be multiplied by the porosity $\left(\theta_{\text {sat }}\right)$ to convert to absolute volumetric soil moisture contents $\left(\mathrm{m}^{3} \mathrm{~m}^{-3}\right)$. The Sentinel-1 satellite has varying overpass densities, resulting in a slightly different number of data-points in various areas, but the temporal resolution is generally between 3 to 8 days. To exclude potential datapoints for days in which the soil was nearly frozen, the soil temperature variable from MERRA-2 was used to identify and remove all data at which the soil temperature was below $4^{\circ} \mathrm{C}$, following the recommended data masking by e.g. Gruber et al. (2020). The CGLS-SSM product contains masks for areas

185 where it cannot be applied, i.e. a water mask, for pixels containing only water, a sensitivity mask, for pixels with a low sensitivity (urban, rivers, dense forests) and a slope mask, screening out pixels with a topographic slope higher than $17^{\circ}$. Since the simulation domain was restricted to agricultural areas, there is an implicit extra quality screening of trivial inferior data.

\subsection{SMAP - SSM}

Surface soil moisture simulations were further evaluated with retrievals from the NASA Soil Moisture Active Passive (SMAP) mission, from April 2015 onwards. More specifically, the enhanced level-2 radiometer half-orbit, version 4, was used at 9-km resolution (O'Neill et al., 2020, Chaubell et al., 2020). The SMAP radiometer measures L-band brightness temperatures in 
https://doi.org/10.5194/gmd-2021-98

Preprint. Discussion started: 17 May 2021

(c) Author(s) 2021. CC BY 4.0 License.

(c) (i)

vertical and horizontal polarization at an incidence angle of $40^{\circ}$. It scans the earth's surface in a sun-synchronous orbit, which is 6:00 A.M. for descending and 6.00 P.M. for ascending mode, and with a temporal resolution of 2-3 days. The SMAP product provides three estimates of surface $(\sim 5 \mathrm{~cm})$ soil moisture $\left(\mathrm{m}^{3} \mathrm{~m}^{-3}\right)$, derived from different retrieval algorithms (O'Neill et al., 2020). The 'Single Channel Algorithm using vertical polarization' is the current baseline for SMAP soil moisture and was also used for AquaCrop evaluations.

SMAP data are projected onto the 9-km EASE grid version 2.0 (EASE2, Brodzik et al., 2012) and the AquaCrop soil moisture output was aggregated to this grid, by simply averaging all $\sim 1-\mathrm{km}$ pixels belonging to the same EASE2 grid cell. Only cells that were at least 50\% filled with AquaCrop output were included for evaluation. The number of AquaCrop pixels per 9-km grid cell varies, depending on the location on the EASE2 grid. For SMAP-SSM, the recommended conservative quality control was applied, and a MERRA-2-based temperature threshold of $4^{\circ} \mathrm{C}$ was applied to exclude nearly frozen soils.

\subsection{In situ - SSM}

In situ soil moisture measurements up to $5 \mathrm{~cm}$ depth were taken from the International Soil Moisture Network (ISMN, Dorigo et al. 2011) to evaluate AquaCrop simulations and satellite soil moisture products. The corresponding soil temperature data

205 were used to exclude the dates with temperatures below $4^{\circ} \mathrm{C}$. Whenever multiple in situ observation points were available within one AquaCrop pixel, the mean of those points was taken. This resulted in a total amount of 42 pixels over Europe where ISMN data could be used to evaluate CGLS-SSM and 32 points for SMAP-SSM, in non-irrigated agricultural areas. AquaCrop simulations were crossmasked with both in situ data and CGLS-SSM to perform an in situ (and satellite-based) evaluation at 42 points. (Crossmasking AquaCrop using in situ and SMAP-SSM data with 32 points resulted in similar metrics for

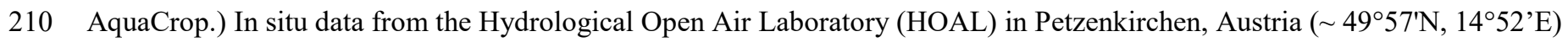
were made available by partners of the SHui consortium and contributed data to three extra clustered pixels, resulting in a total of 45 evaluation points with CGLS-SSM.

\subsection{Metrics}

The regional model was run over a part of Europe $\left(35^{\circ} \mathrm{N}-55^{\circ} \mathrm{N}, 10^{\circ} \mathrm{E}-20^{\circ} \mathrm{E}\right.$; and all ISMN sites), for the years 2011 through 215 2018. Daily simulated biomass and surface soil moisture (WC01 in AquaCrop) were evaluated. To assess the temporal performance of the AquaCrop model, the temporal Pearson correlation (R), anomaly correlation (anomR), bias and unbiased root mean square difference (ubRMSD) were calculated against satellite and in situ products. Comparing products with different spatial resolutions will always result in representativeness bias, which is especially acute when using in situ observations to evaluate pixel-scale estimates. Therefore, the focus of the evaluation will be on temporal variability, using the

$220 \mathrm{R}$, anomR and ubRMSD metrics.

The time period used for validation depended on the evaluation product. When using satellite-based soil moisture, only grid cells were included when at least 150 CGLS-SSM or 200 SMAP-SSM retrievals (after quality control) were available during 
https://doi.org/10.5194/gmd-2021-98

Preprint. Discussion started: 17 May 2021

(c) Author(s) 2021. CC BY 4.0 License.

(c) (i)

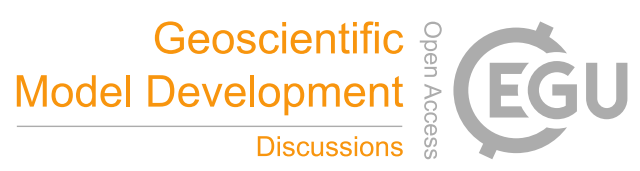

the overlapping period of satellite data (starting in 2014 for CGLS-SSM and in 2015 for SMAP-SSM) and simulations. When further comparing the satellite products to in situ data, a relaxed minimal threshold of 100 data pairs was set for the period of available data for each satellite product. For CGLS-DMP, the 10-daily data are complete between 2011-2018 and only March through November are included in the evaluation metrics.

The anomR was computed to assess both the short term and inter-annual variability of biomass and soil moisture compared to the satellite products only, for lack of sufficiently long records of in situ data. A multi-year climatology was computed and subtracted from the datasets to obtain anomalies. The climatology is built on 31-day moving window averages, requiring either a minimum of 3 10-daily CGLS-DMP estimates or a minimum of 10 instantaneous CGLS-SSM and SMAP-SSM observations within a 31-day window. The climatology of AquaCrop was computed using the same moving window and time period as the evaluation product. For surface soil moisture, only daily model output that matched the days of observations of the evaluation product was used, whereas for biomass evaluations, the data consisted of the matching 10-daily medians.

To further analyse possible influencing factors on the model performance, the FAO map 'Area Equipped for Irrigation' (AEI:

235 Siebert et al., 2015), was used to identify areas that are occasionally irrigated and not necessarily captured by the irrigation class the Corine land cover inventory, which only considers regularly irrigated areas. The available 1-km and 10-km AEI map version were used to stratify correlation values with CGLS-DMP and with SMAP-SSM, respectively.

\section{Results and discussion}

\subsection{Biomass}

240 A visual comparison of simulated and satellite-based biomass at different days in the year of 2017 is presented in Fig. 1 and gives an indication of the spatial performance of the regional AquaCrop model against the CGLS-DMP product. The figure shows that the model is able to capture large regional and temporal differences in biomass production, but the absolute values can differ between CGLS-DMP and the model. The coarser resolution MERRA-2 climate input is visible in the blocky pattern of the AquaCrop biomass maps. For the days in June and July, simulations over most of Italy ceased to produce biomass, whereas the CGLS-DMP product shows spatial variability in productivity. Water stress in the simulations is putting crop production to a halt, which is not in agreement to the CGLS-DMP. This can be either caused by an overestimation of water stress by the model, unmodelled irrigation, or because the CGLS-DMP product does not account well for drought stresses. Drought stress is indirectly included in the CGLS-DMP via the observed fAPAR, but could still lead to overestimations of DMP in drier periods (Smets et al., 2019).

250 Figure 2a summarizes the performance metrics of AquaCrop biomass simulations against CGLS-DMP. Differences in absolute values of biomass estimates are inevitable, because of representativeness errors in both the model and satellite retrievals. For example, the model uses a generic crop, for which the parameters could be locally optimized. Nevertheless, the long-term biases are limited and cancel out over the entire domain. When focussing on the temporal variability, the temporal correlations indicate a high performance, with an overall mean of $\mathrm{R}=0.8$. Higher correlations are mostly found in the northern part of 
https://doi.org/10.5194/gmd-2021-98

Preprint. Discussion started: 17 May 2021

(c) Author(s) 2021. CC BY 4.0 License.

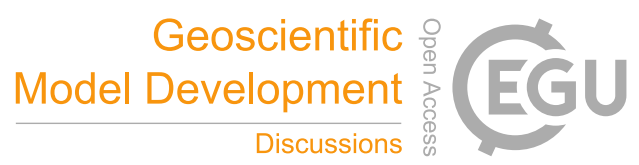

255 Europe. Lower correlations are specifically found in the North and Southwest of Italy. Similarly, the ubRMSD is highest in the southern half of the study domain.

The spatial variability in ubRMSD can be attributed to different factors that limit crop growth, which will be mostly cold temperatures in the North, and low soil water contents in the South. Across the domain the ubRMSD is $0.03 \mathrm{~T} \mathrm{ha}^{-1} \mathrm{day}^{-1}$ and typically less than $20 \%$ of the amplitude in biomass production. The anomaly correlation is lower than the correlation, but still

260 significant, with a mean of anomR $=0.46$. The raw correlation includes the trivial agreement in the seasonal variability and is thus inevitably higher, whereas the anomaly correlation only evaluates short-term and interannual variability, as illustrated in Fig. $2 b$ for the HOAL catchment in Austria.

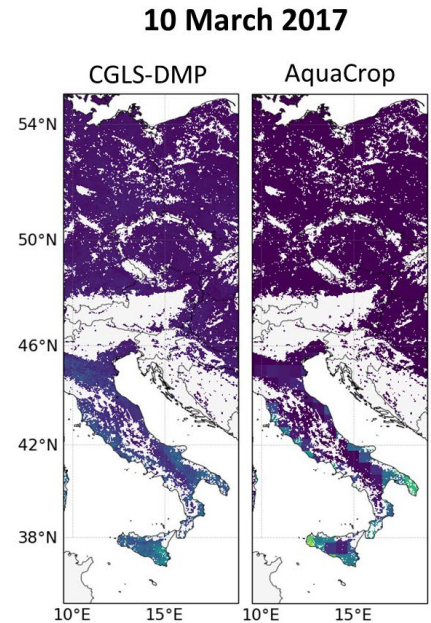

10 July 2017

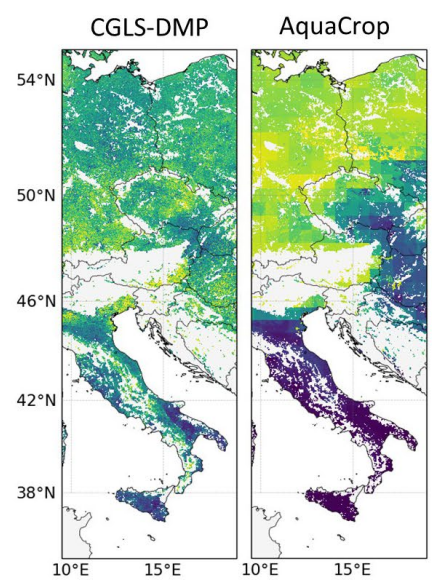

10 April 2017

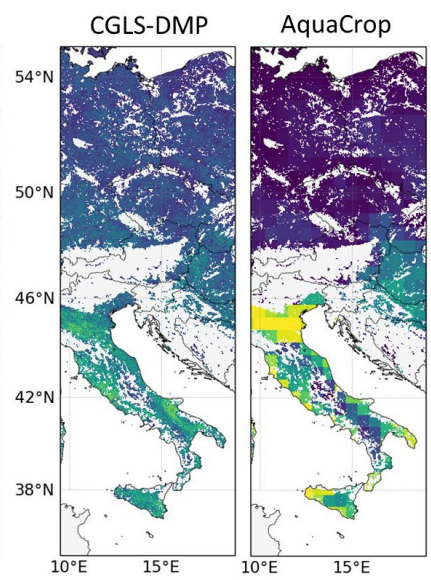

10 August 2017

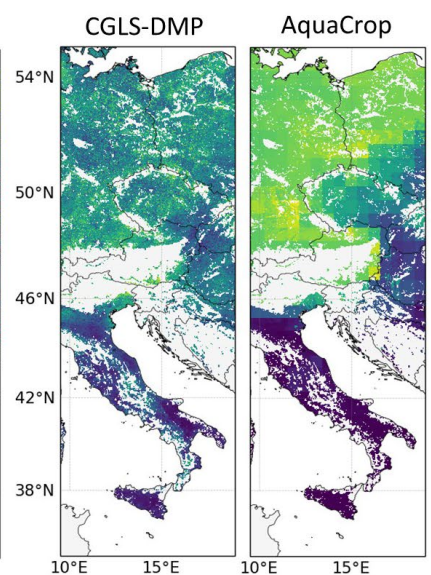

10 May 2017

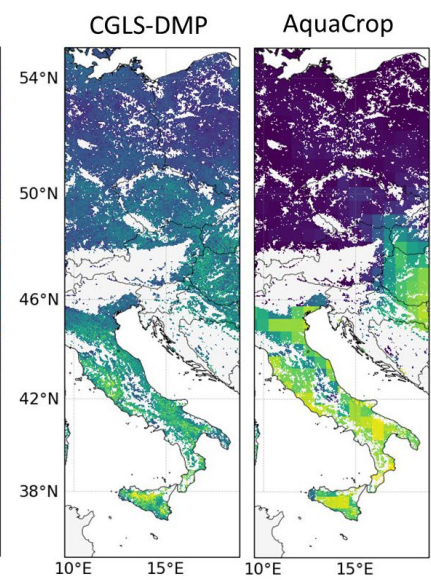

10 September 2017

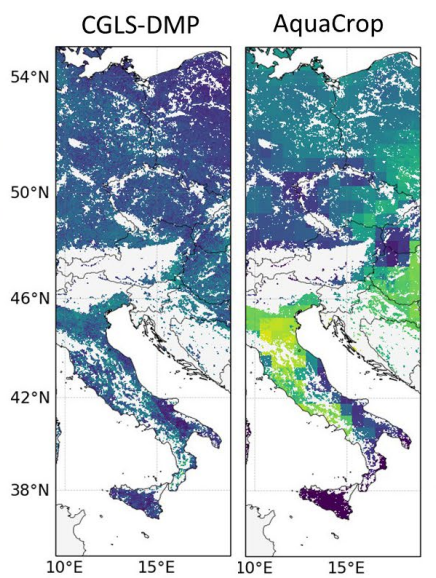

10 June 2017

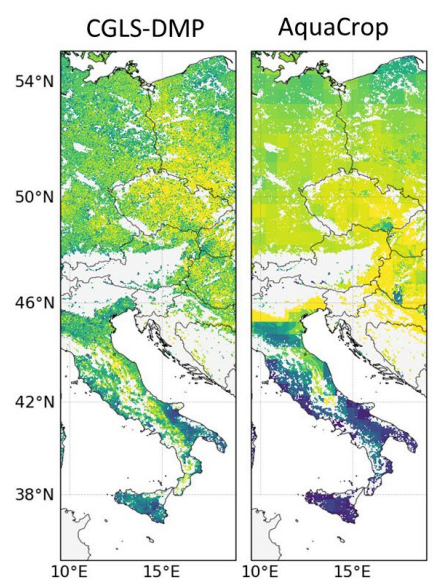

10 October 2017

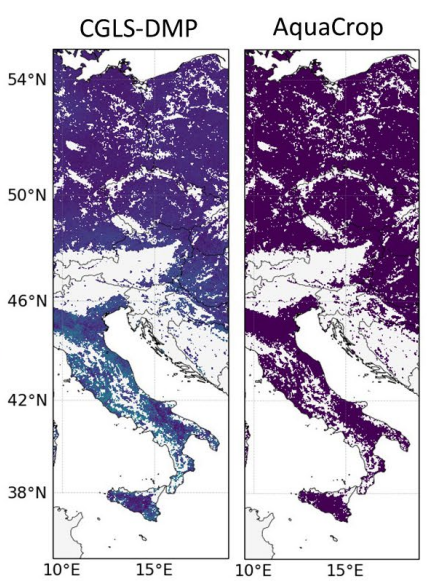

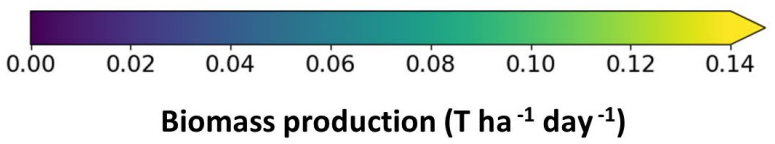

Figure 1. Biomass production of CGLS-DMP and AquaCrop during different days of the year 2017. 
Both the model and satellite data show anomalous high biomass production in June 2017, whereas anomalous low values are found in both datasets in June 2013. The short-term anomaly biomass productivity increments are also corresponding well to the evaluation data, but for AquaCrop they are often more pronounced. Across the region, the lower anomaly correlation values can be partly associated with soil texture. In areas with typically sandy soils, defined by a low TAW and high $\mathrm{K}_{\text {sat, }}$ and a high rate of rainfall, such as northern Germany and Poland, soils can be quickly drained, resulting in water stress, thereby limiting crop growth, even during the main growth season. The effect of such stresses may not be observed in the CGLS-DMP, and will result in deviating interannual variabilities.

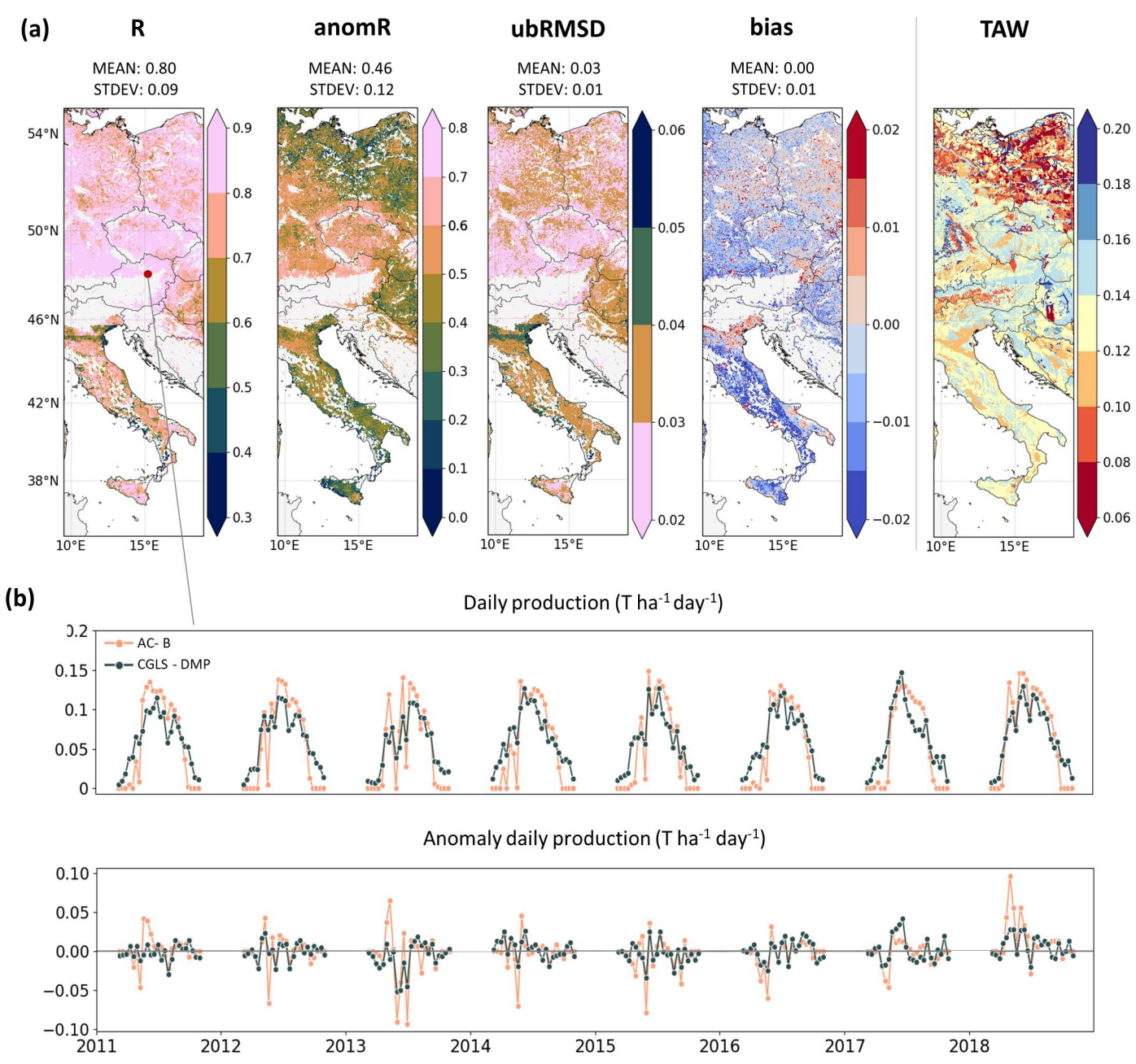

Figure 2 (a) Temporal performance metrics of AquaCrop biomass evaluated against CGLS-DMP, i.e. R (-),_anomR $(-)$, bias $\left(\mathrm{T} \mathrm{ha}^{-1} \mathrm{day}^{-1}\right)$, ubRMSD $\left(\mathrm{T} \mathrm{ha}^{-1}\right.$ day $\left.^{-1}\right)$, with indication of the spatial mean and standard deviation of the metrics (MEAN, STDEV). Also shown is the TAW $\left(\mathrm{m}^{3} \mathrm{~m}^{-3}\right)$ computed as the field capacity minus wilting point, without taking rooting depth into account. (b) Time series of biomass production within (red dot in A) the HOAL catchment in Austria, for (orange) 1-km AquaCrop daily biomass simulations and anomalies and (dark blue) CGLSDMP data and anomalies 
https://doi.org/10.5194/gmd-2021-98

Preprint. Discussion started: 17 May 2021

(c) Author(s) 2021. CC BY 4.0 License.

(c) (i)

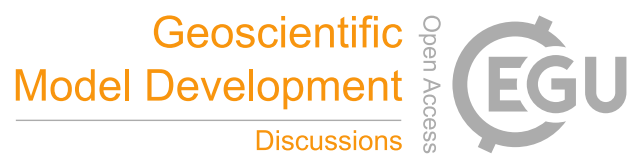

\subsection{Surface moisture content}

Surface soil moisture content was evaluated using three products at different scales; point measurements from ISMN and some additional sites in the HOAL catchment, 1-km CGLS-SSM and 9-km SMAP-SSM. Figure 3 shows the AquaCrop performance metrics against the satellite data. The spatial mean R and anomR value with SMAP retrievals are 0.74 and 0.65 , respectively. The anomR is especially high in the central part of Europe and decreases towards the North. Overall, AquaCrop is much better correlated with SMAP-SSM than with CGLS-SSM. The mean R and anomR value of AquaCrop with CGLS-SSM are 0.52 and 0.50, respectively. Several areas with higher elevations have lower correlation values (central Italy, eastern Alps).

When looking at the absolute values of the bias and ubRMSD, the evaluation of AquaCrop against CGLS-SSM is also far worse than that against SMAP-SSM, but the spatial pattern of the errors is similar for SMAP-SSM and CGLS-SSM. The spatial mean ubRMSD against SMAP-SSM is $0.05 \mathrm{~m}^{3} \mathrm{~m}^{-3}$, close to the global target product uncertainty of $0.04 \mathrm{~m}^{3} \mathrm{~m}^{-3}$ 280 (Entekhabi et al., 2014). For both datasets, the larger errors correspond again to areas with sandy soils. ubRMSD values of $0.14 \mathrm{~m}^{3} \mathrm{~m}^{-3}$ and higher for CGLS-SSM, correspond to outliers in the HWSDv1.2 classification of extremely sandy soils (93\% sand). This soil class is characterised by very high $\mathrm{K}_{\mathrm{sat}}$ and very low values for $\theta_{\mathrm{WP}}$ and $\theta_{\mathrm{FC}}$, resulting in extremely low simulated available moisture content in the top layers. Because the low $\theta_{\mathrm{WP}}$ is very close to the soil evaporation demand, the model is not able to simulate soil moisture correctly for the top layers for such short, daily timesteps. It is important to note that 285 AquaCrop is a crop simulation model and this soil class is unrealistic for agricultural land. In future applications, it is recommended to limit the simulations to soils that are actually suitable to cultivate crops, or else to adapt the soil parameters. Nonetheless, the poor performance against the 1-km Sentinel-1-based CGLS-SSM is in general not due to model shortcomings, but dominated by poor satellite retrievals, as will be discussed below. 


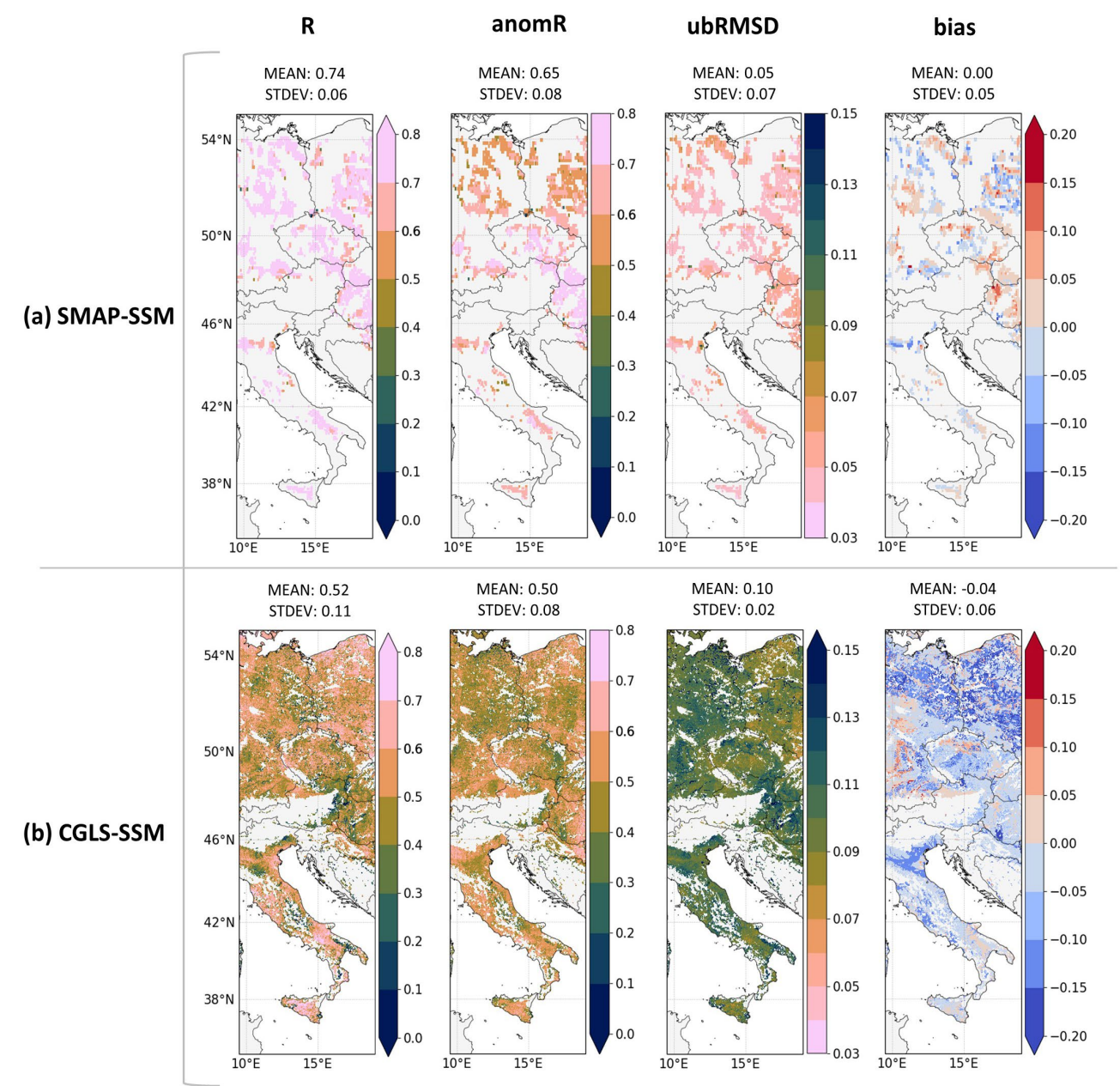

Figure 3 Temporal performance metrics of AquaCrop surface soil moisture evaluated against (a) SMAP-SSM and (b) CGLS-SSM, i.e. R (-), anomR (-), bias $\left(\mathrm{m}^{3} \mathrm{~m}^{-3}\right)$ and ubRMSD $\left(\mathrm{m}^{3} \mathrm{~m}^{-3}\right)$, with indication of the spatial mean and standard deviation of the metrics (MEAN, STDEV).

A comparison between in situ data, CGLS-SSM, SMAP-SSM and AquaCrop surface soil moisture at ISMN sites and 3 sites

in the HOAL catchment is shown in Fig. 4. Across 45 in situ sites, the mean R value between AquaCrop and in situ soil moisture is 0.61 (Fig. 4a) and higher than the mean R value of 0.52 with CGLS-SSM (Fig. 4b). The mean ubRMSD between AquaCrop and in situ measurements is $0.06 \mathrm{~m}^{3} \mathrm{~m}^{-3}$, significantly lower than the mean between AquaCrop and CGLS-SSM $\left(0.10 \mathrm{~m}^{3} \mathrm{~m}^{-3}\right)$. The mean $\mathrm{R}$ between Sentinel-1 CGLS-SSM and in situ is even lower, with a value of 0.42 and a mean ubRMSD of $0.11 \mathrm{~m}^{3} \mathrm{~m}^{-3}$ (Fig. 4c). The comparison with SMAP-SSM over 42 in situ sites shows that SMAP-SSM correlates significantly better with both AquaCrop $\left(\mathrm{R}=0.81\right.$, ubRMSD $\left.=0.05 \mathrm{~m}^{3} \mathrm{~m}^{-3}\right)$ and in situ measurements $\left(\mathrm{R}=0.69\right.$, ubRMSD $\left.=0.05 \mathrm{~m}^{3} \mathrm{~m}^{-3}\right)$, even though the product has a lower spatial resolution than CGLS-SSM. This is further illustrated in the time series at three locations presented in Fig. 5, where SMAP-SSM follows the pattern of in situ data well and slightly better than AquaCrop, whereas the 
pattern of the CGLS-SSM values is more erratic. The high correlations between SMAP-SSM and in situ measurements show that SMAP-SSM is better at capturing variations at smaller scales than the current system of AquaCrop, due the coarse resolution of meteorological input data. Additionally, SMAP-SSM retrievals probably benefit from a more accurate background representation of the vegetation, whereas AquaCrop uses a generic crop description.

For CGLS-SSM, lower observed soil moisture was often found for the months April, May and June, as can be seen in Fig. 5b and c. The poor correlation of CGLS-SSM during these months is most likely due to the fact that the Sentinel-1 backscatter signals are dynamically affected by changing vegetation during the growing season, but the soil moisture retrievals are only corrected for with a static vegetation value for every day of the year. Furthermore, changes in surface soil roughness are not accounted for in the retrievals and could play an important role in the lower quality of the CGLS-SSM retrievals.

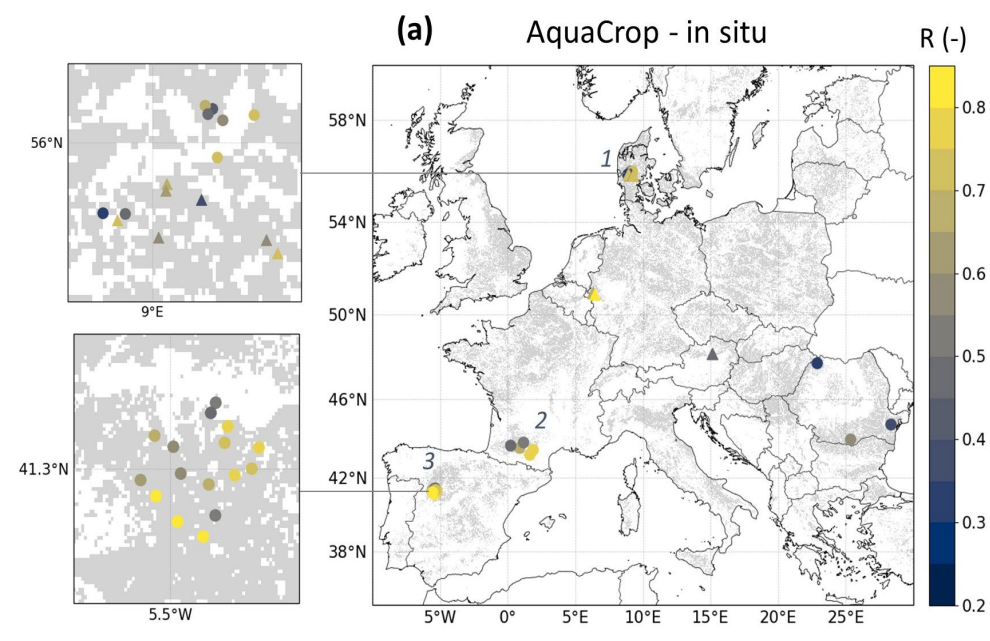

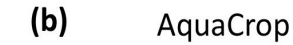

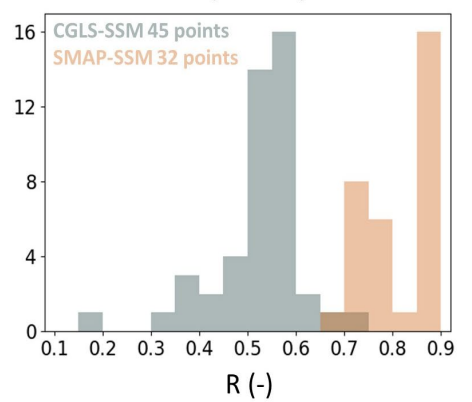

(c) in situ

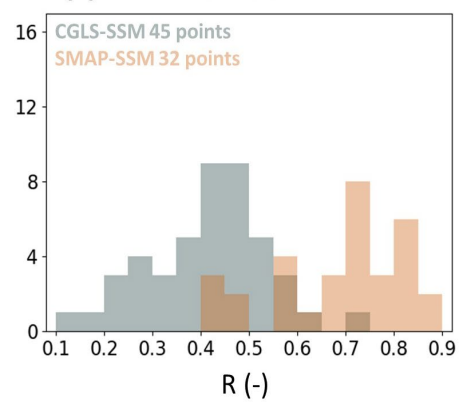

Figure 4 (a). Pearson correlation R values between in situ measurements from the ISMN and AquaCrop surface soil moisture, at 45 locations over Europe, with grey pixels containing at least 50\% rainfed agriculture according to the CORINE land cover map 2012. Correlations shown are from crossmasked data with CGLS-SSM. The circles indicate the locations used for both evaluation with CGLS-SSM and SMAP-SSM, whereas triangles show locations that were only used for CGLS-SSM. (b) Histogram of R values between AquaCrop surface soil moisture and the satellite products CGLS-SSM (45 points) and SMAPSSM (32 points), at the locations of the in situ sites. (c) Histogram of the R values between the in situ measurements and the satellite products CGLS-SSM (45 points) and SMAP-SSM (32 points). 


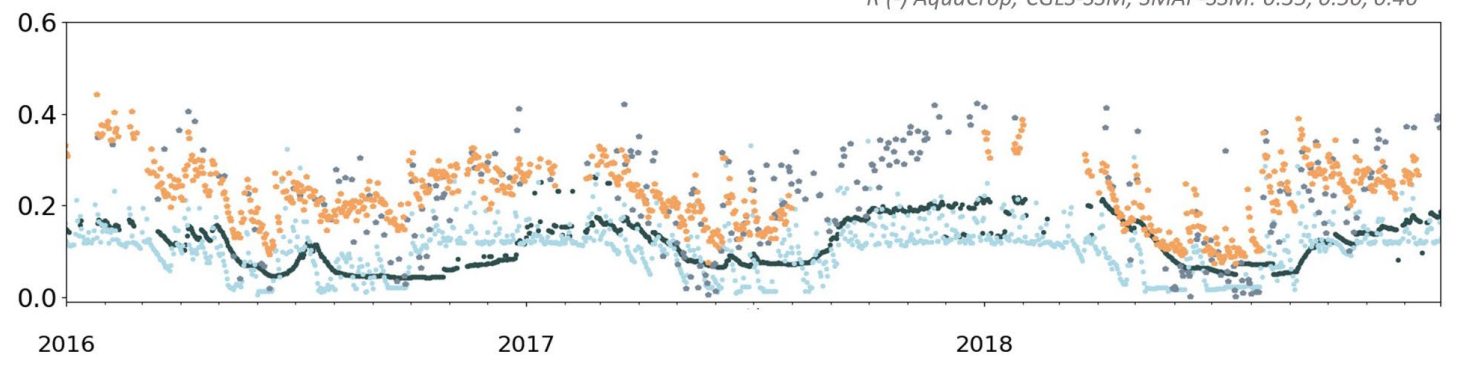

2. SMOSMANIA - Peyrusse Grande surface soil moisture

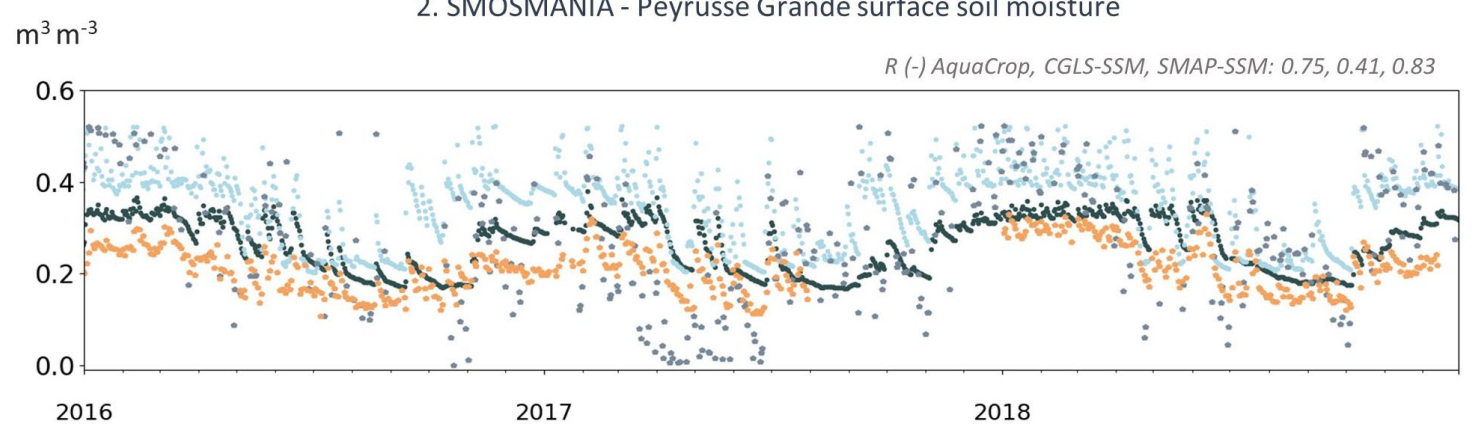

3. REMEDHUS - La Cruz de Elias surface soil moisture

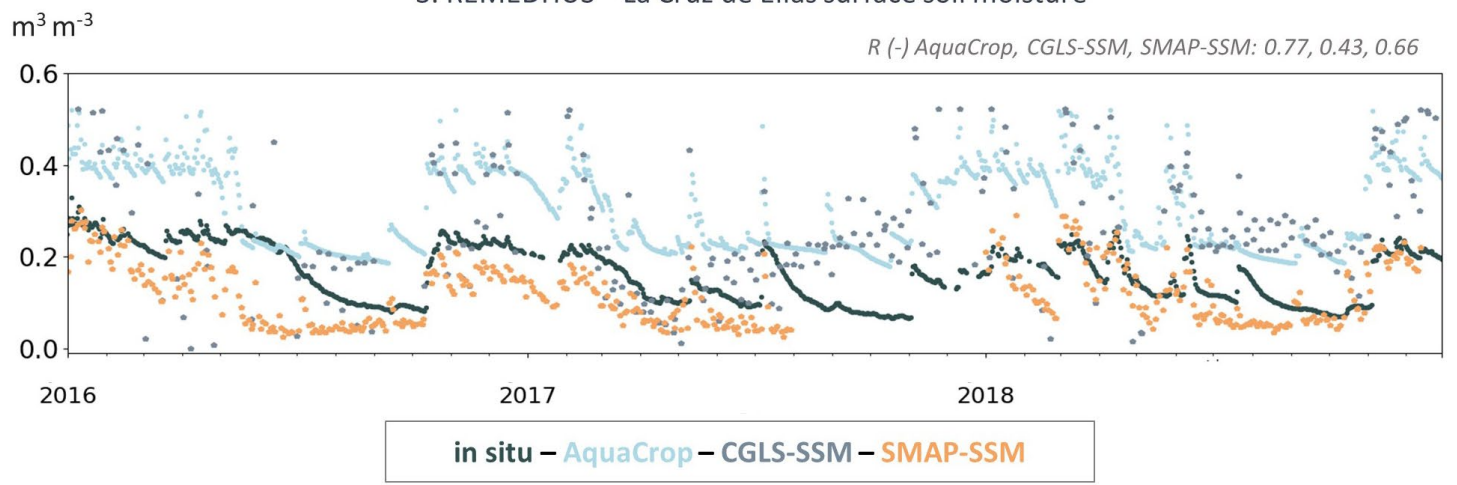

Figure 5 Time series of daily surface soil moisture at three locations marked in Fig. $4 \mathrm{a}: 1\left(\sim 55^{\circ} 54 \mathrm{~N}, 8^{\circ} 52 \mathrm{E}\right), 2\left(\sim 41^{\circ} 17 \mathrm{~N}\right.$, $\left.5^{\circ} 18 \mathrm{~W}\right)$ and $3\left(\sim 43^{\circ} 39 \mathrm{~N}, 0^{\circ} 13 \mathrm{E}\right)$ : AquaCrop (light blue) in situ measurements (dark grey), CGLS-SSM (light grey) and SMAP-SSM (orange). Pearson correlations of in situ data with the different products are given for each location. 


\subsection{Effect of irrigation}

Figure 6 shows the spatial distribution of the R values of AquaCrop biomass and soil moisture with CGLS-DMP and SMAP-

SSM, respectively, grouped into two percentage classes of AEI. In terms of biomass, higher R-values between AquaCrop and CGLS-DMP (mean $\mathrm{R}=0.81$ ) are found for pixels where AEI $<10 \%$ than for areas where AEI $>=10 \%$ (mean $\mathrm{R}=0.72$ ). For soil moisture, the correlation with SMAP-SSM shows barely any difference between the AEI groups (AEI $<10 \%$ : mean $\mathrm{R}=$ 0.74; $\mathrm{AEI}>=10 \%$ : mean $\mathrm{R}=0.73$ ). It should be noted that SMAP-SSM has a much smaller coverage than the CGLS-DMP, because SMAP-SSM is screened conservatively based on its quality flags. The results of this comparison suggest that, even if the simulations were limited to dominantly rainfed agricultural areas, a possible effect of irrigation on the correlation between the model and evaluation datasets should not be neglected.

(a)

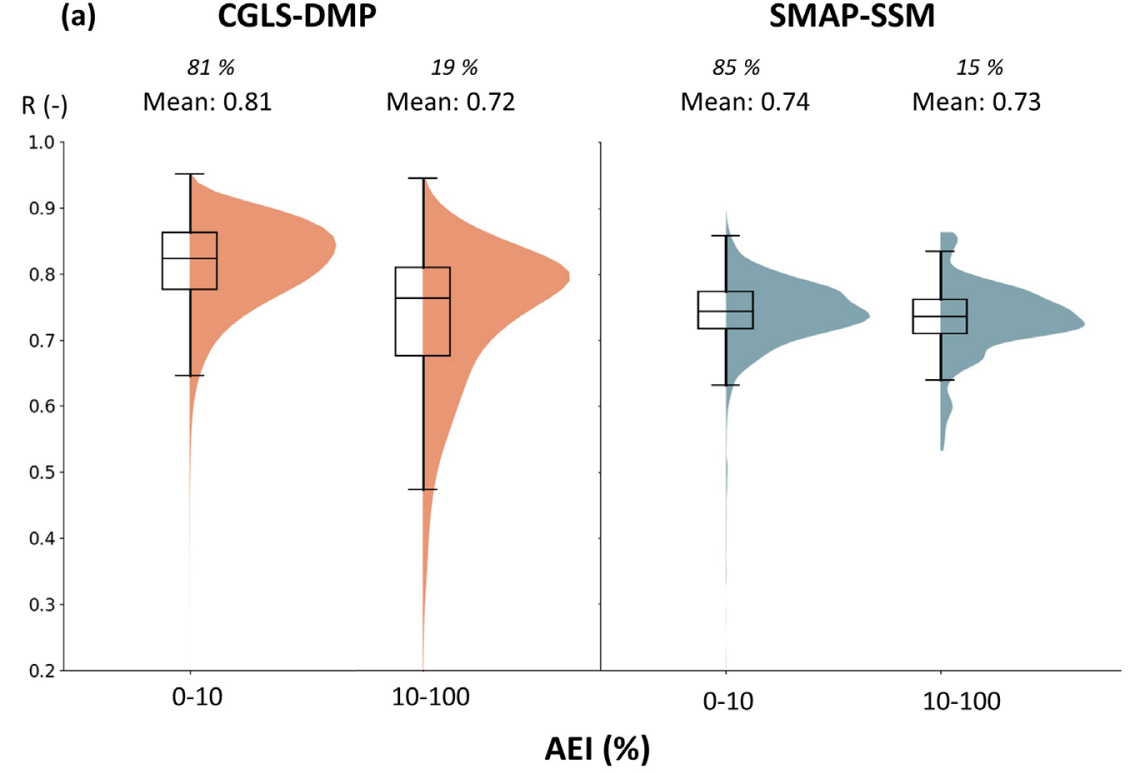

(b)

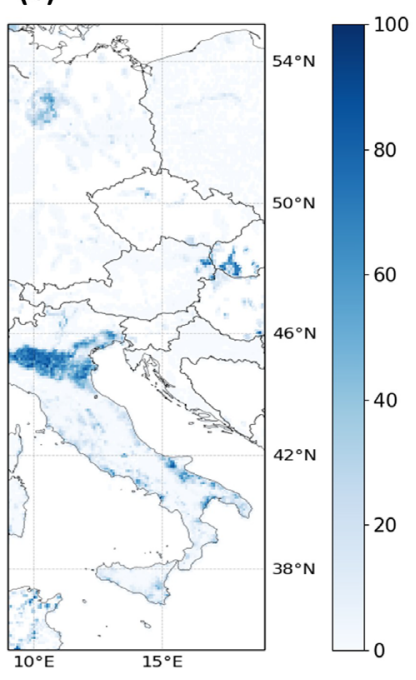

Figure 6 (a) Boxplots with violin curve of temporal R values grouped by FAO's percentage of Area Equipped for Irrigation (AEI), group1: $0-10 \%$ and group2: $10-100 \%$, on the left side for CGLS-DMP and on the right side for SMAP-SSM. The percentage of the total amount of pixels for each group, and the spatial mean R value is noted at the top of the figure. (b) AEI map over study domain.

\section{Conclusions}

In this paper, a spatially distributed version of the field-scale AquaCrop model v6.1 is presented and evaluated against various satellite data products and in situ data. The new regional AquaCrop infrastructure allows to simulate biomass and soil moisture over large domains in an efficient way, due to the massive parallelization of the gridded simulations. In this case study, the 
https://doi.org/10.5194/gmd-2021-98

Preprint. Discussion started: 17 May 2021

(c) Author(s) 2021. CC BY 4.0 License.

(c) (i)

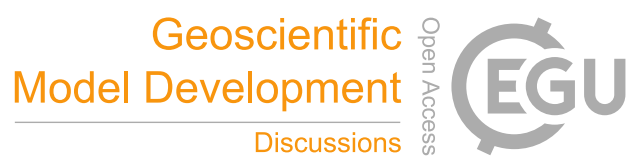

regional AquaCrop model is forced with meteorological input based on MERRA-2 re-analysis data, the soil information is extracted from the HWSDv1.2, and a generic crop is parameterized. Even when using coarse meteorological input data, the AquaCrop model is able to capture seasonal, interannual and short-term temporal dynamics of biomass over Europe at a fine $\sim 1-\mathrm{km}$ resolution. For the years 2011 through 2018 the temporal $\mathrm{R}$ between the AquaCrop biomass production and CGLSDMP is 0.8 , and the anomR is 0.46 , across central Europe. The $\mathrm{R}$ values are higher in the northern half of the study domain, where crop growth is generally temperature limited, whereas in the southern half of the domain, water stress becomes more important and the $\mathrm{R}$ values are lower. Likely factors that can influence this difference in correlation are an underrepresentation of drought stress by the CGLS-DMP product, the effect of occasionally applied irrigation which is not included in the model, or possibly overestimations of simulated drought stress by the model. Additionally, the impact of soil parameters is apparent in the anomR values, where lower TAW values in the northern part result in differing anomalies for modelled biomass and CGLS-DMP.

The AquaCrop simulations for surface moisture content show that seasonal, interannual and short-term temporal dynamics correspond well to the SMAP-SSM data, with a mean $\mathrm{R}$ value of 0.75 and an anomR value of 0.65 across the study domain. Lower R values are found for Sentinel-1 CGLS-SSM, with a mean temporal R of 0.52 and a similar anomR of 0.50 . The comparison between AquaCrop, CGLS-SSM, SMAP-SSM and in situ data for 45 (32 for SMAP-SSM) locations in Europe shows that both AquaCrop and SMAP-SSM better agree with in situ data (mean R=0.61, 0.69, respectively) than Sentinel-1 CGLS-SSM (mean R= 0.52). The lower performance of Sentinel-1 CGLS-SSM can be attributed to the static correction for vegetation, which causes soil moisture retrieval errors during the growing season, and the fact that there is no correction for surface roughness. For both the evaluations with SMAP and Sentinel-1 retrievals, the effect of soil characteristics influences the evaluation performance of the AquaCrop model. When certain soil characteristics are unsuitable for crop cultivation, such as a high $\mathrm{K}_{\text {sat }}$ and a very low $\theta_{\mathrm{WP}}$ and low TAW, soil moisture becomes inaccurately represented by the AquaCrop model, increasing the model error. At the same time, the errors in satellite retrievals might also differ for various soil textures.

Improvements to the regional AquaCrop model can be made in terms of higher resolution meteorological input data to better capture small-scale spatial differences, by revising the soil hydraulic parameters to better represent soil types used for 345 agricultural land, and by introducing spatio-temporally varying crop parameters when such information becomes available. Overall, the current model is able to well represent temporal and spatial differences at the field and regional scale in both biomass production and surface soil moisture, requiring only easily accessible input data. The computationally efficient modelling system is ideal to foster future improvements in the spatial patterns in both soil moisture and biomass production via local parameter optimization based on historical records of satellite data, and improvements in the short-term and interannual temporal variations via sequential satellite data assimilation.

Code and data availability. The code and data needed to run the regional version of AquaCropv6.1 on a Linux-based system are currently only available to the editors and reviewers. After acceptance, a repository will be made publicly available on 
https://doi.org/10.5194/gmd-2021-98

Preprint. Discussion started: 17 May 2021

(c) Author(s) 2021. CC BY 4.0 License.

(c) (i)

Zenodo with a citable DOI. Apart from the code, this repository will include the generic crop file, the management file and ancillary soil data from De Lannoy et al. (2014). All other input data and evaluation datasets are freely available, except for the in situ measurements of the HOAL experiment site. Please visit the following links for data access.

MERRA-2 variables (accessed on March 2019): https://disc.gsfc.nasa.gov/datasets?project=MERRA-2; the soil mineral classification and organic matter originates from HWSDv1.2: http://www.fao.org/soils-portal/data-hub/soil-maps-anddatabases/harmonized-world-soil-database-v12/en/; the Corine land cover map (accessed on September 2019): https://land.copernicus.eu/pan-european/corine-land-cover; the rootzone depth map from ESDAC (accessed on October 2019): https://esdac.jrc.ec.europa.eu/content/european-soil-database-derived-data; evaluation datasets from COPERNICUS Global Land Service (CGLS-DMP, CGLS-SSM; accessed on February 2020, June 2020): https://land.copernicus.eu/global/themes/vegetation; SMAP Enhanced L2 Radiometer Half-Orbit 9 km EASE-Grid Soil Moisture, Version 4 (accessed on September 2020): https://nsidc.org/data/SPL2SMP_E/versions/4; ISMN soil moisture at 5 cm depth (accessed on August 2020): https://ismn.geo.tuwien.ac.at/en/; FAO irrigation maps (accessed on June 2020): http://www.fao.org/aquastat/en/geospatial-information/global-maps-irrigated-areas.

Author contributions. SDR created the code to execute the regional version of the model, prepared the input data and conducted the model evaluation. GDL prioritised the main steps taken in the paper, provided supervision and scientific guidance throughout all research advances and manages HPC usage. DR provided scientific guidance regarding the use and interpretation of the AquaCrop model, developed the generic crop file, and provided the Delphi source code of AquaCropv6.1. SDR wrote the paper and all authors contributed.

Competing interests. The authors declare that they have no conflict in interest.

Acknowledgements. The authors would like to thank the HPC VSC team, in particular Geert-Jan Bex and Martijn Oldenhof, for their help during the AquaCrop compilation on the VSC HPC. We would also like to thank Peter Strauss and Gerhard Rab from Vienna University of Technology (TU Wien) for sharing their data from the HOAL experiment site, and Stefan Siebert for providing a 1-km map with area equipped for irrigation.

Financial support. This research is conducted as part of the H2020 project SHui, that stands for "Soil Hydrology research platform underpinning innovation to manage water scarcity in European and Chinese cropping systems". SHui is co-funded by the European Union Project GA 773903 and the Chinese MOST. 


\section{References}

Abedinpour, M., Sarangi, A., Rajput, T. B. S., Singh, M., Pathak, H., and Ahmad, T.: Performance evaluation of AquaCrop model for maize crop in a semi-arid environment, Agr. Water Manage., 110, 55-66, https://doi.org/10.1016/j.agwat.2012.04.001, 2012.

Allen, R. G., Pereira, L. S., Raes, D., and Smith, M.: Crop evapotranspiration-Guidelines for computing crop water requirements, FAO Irrigation and drainage paper 56, FAO, Rome, Italy, ISBN 92-5-104219-5, 1998.

Asseng, S., Ewert, F., Rosenzweig, C., Jones, J. W., Hatfield, J. L., Ruane, A. C., Boote, K. J., Thorburn, P. J., Rötter, R. P., Cammarano, D., Brisson, N., Basso, B., Martre, P., Aggarwal, P. K., Angulo, C., Bertuzzi, P., Biernath, C., Challinor, A. J., Doltra, J., Gayler, S., Goldberg, R., Grant, R., Heng, L., Hooker, J., Hunt, L. A., Ingwersen, J., Izaurralde, R. C., Kersebaum, K. C., Müller, C., Naresh Kumar, S., Nendel, C., O’Leary, G., Olesen, J. E., Osborne, T. M., Palosuo, T., Priesack, E., Ripoche, D., Semenov, M. A., Shcherbak, I., Steduto, P., Stöckle, C., Stratonovitch, P., Streck, T., Supit, I., Tao, F., Travasso, M., Waha, K., Wallach, D., White, J. W., Williams, J. R., and Wolf, J.: Uncertainty in simulating wheat yields under climate change, Nat. Clim. Change, 3, 827-832, https://doi.org/10.1038/nclimate1916, 2013.

Aznar-Sánchez, J. A., Piquer-Rodríguez, M., Velasco-Muñoz, J. F., and Manzano-Agugliaro, F.: Worldwide research trends on sustainable land use in agriculture, Land use policy, 87, 104069, https://doi.org/10.1016/j.landusepol.2019.104069, 2019.

Boogaard, H., Wolf, J., Supit, I., Niemeyer, S., and van Ittersum, M.: A regional implementation of WOFOST for calculating yield gaps of autumn-sown wheat across the European Union, Field Crops Res., 143, 130-142, https://doi.org/10.1016/j.fcr.2012.11.005, 2013.

Balkovic, J., van der Velde, M., Schmid, E., Skalský, R., Khabarov, N., Obersteiner, M., Stürmer, B., and Xiong, W.: PanEuropean crop modelling with EPIC: Implementation, up-scaling and regional crop yield validation, Agr. Syst., 120, 6175, https://doi.org/10.1016/j.agsy.2013.05.008, 2013.

Bauer-Marschallinger, B., Freeman, V., Cao, S., Paulik, C., Schaufler, S., Stachl, T., Modanesi, S., Massari, C., Ciabatta L., Brocca L., and Wagner, W.: Toward global soil moisture monitoring with Sentinel-1: Harnessing assets and overcoming obstacles, IEEE T. Geosci. Remote, 57, 520-539, 520-539, https://doi.org/10.1109/TGRS.2018.2858004, 2018.

Boogaard, H., Wolf, J., Supit, I., Niemeyer, S., and van Ittersum, M.: A regional implementation of WOFOST for calculating yield gaps of autumn-sown wheat across the European Union, Field Crop. Res., 143, 130-142, https://doi.org/10.1016/j.fcr.2012.11.005, 2013.

Brodzik, M. J., Billingsley, B., Haran, T., Raup, B., and Savoie, M. H.: EASE-Grid 2.0: Incremental but significant improvements for Earth-gridded data sets, ISPRS Int. Geo-Inf., 1, 32-45, https://doi.org/10.3390/ijgi1010032, 2012.

Büttner, G.: CORINE land cover and land cover change products, Land use and land cover mapping in Europe, Springer, Dordrecht, The Netherlands, 55-74 pp, https://doi.org/10.1007/978-94-007-7969-3, 2014. 
https://doi.org/10.5194/gmd-2021-98

Preprint. Discussion started: 17 May 2021

(c) Author(s) 2021. CC BY 4.0 License.

Chaubell, M. J., Yueh, S. H., Dunbar, R. S., Colliander, A., Chen, F., Chan, S. K., Entekhabi, D., Bindlish, R., O'Neill, P. E., Asanuma, J., Berg, A. A., Bosch, D. D., Caldwell, T., Cosh, M. H., Collins, C. H., Martinez-Fernandez, J., Seyfried, M., Starks, P. J., Su, Z., Thibeault, M., and Walker, J.: Improved SMAP Dual-Channel Algorithm for the Retrieval of Soil Moisture, IEEE T. Geosci. Remote, 58, 3894-3905, https://doi.org/10.1109/TGRS.2019.2959239, 2020.

Dale, A., Fant, C., Strzepek, K., Lickley, M., and Solomon, S.: Climate model uncertainty in impact assessments for agriculture: A multi-ensemble case study on maize in sub-Saharan Africa, Earth's Future, 5, 337-353, https://doi.org/10.1002/2017EF000539, 2017.

De Lannoy, G. J., Koster, R. D., Reichle, R. H., Mahanama, S. P., and Liu, Q.: An updated treatment of soil texture and associated hydraulic properties in a global land modeling system, J. Adv. Model. Earth Sy., 6, 957-979, https://doi.org/10.1002/2014MS000330, 2014.

De Wit, A. D., and Van Diepen, C. A.: Crop model data assimilation with the Ensemble Kalman filter for improving regional crop yield forecasts, Agr. and Forest Meteorol., 146, 38-56, https://doi.org/10.1016/j.agrformet.2007.05.004, 2007.

Di Paola, A., Valentini, R., and Santini, M.: An overview of available crop growth and yield models for studies and assessments in agriculture, J. Sci. Food Agr., 96, 709-714, https://doi.org/10.1002/jsfa.7359, 2016.

Dorigo, W. A., Wagner, W., Hohensinn, R., Hahn, S., Paulik, C., Xaver, A., Gruber, A., Drusch, M., Mecklenburg, S., van Oevelen, P., Robock, A., and Jackson T.: International Soil Moisture Network: a data hosting facility for global in situ soil moisture measurements, Hydrol. Earth Syst. Sc., 15, 1675-1698, https://doi.org/10.5194/hess-15-1675-2011, 2011.

Entekhabi, D., Yueh, S., O'Neill, P., Kellogg, K. H., Allen, A., Bindlish, R., Brown, M., Chan, S., Colliander, A., Crow, W. T, Das, N., De Lannoy, G., Dunbar, R. S., Edelstein, W. N., Entin, J. K., Escobar, V., Goodman, S. D., Jackson, T. J., Jai, B., Johnson, J., Kim, E., Kim, S., Kimball, J., Koster, R. D., Leon, A., McDonald, K. C., Moghaddam, M., Mohammed, P., Moran, S.,; Njoku, E. G., Piepmeier, J. R., Reichle, R., Rogez, F., Shi, J. C., Spencer, M. W., Thurman, S. W., Tsang, L., Van Zyl, J., Weiss, B., and West, R.: SMAP Handbook-soil moisture active passive: Mapping soil moisture and freeze/thaw from space, JPL publication, Pasadena, California USA, 192 pp., JPL 400-1567, 2014.

FAO: The future of food and agriculture-Trends and challenges, Annual Report, FAO, Rome, Italy, ISBN 978-92-5-1095515, 2017.

Feddes, R.A..: Simulation of field water use and crop yield, in: Simulation of plant growth and crop production, Penning de Vries, F.W.T., and van Laar H. H., Pudoc, Wageningen, the Netherlands, 194-209 pp., ISBN 9789022008096, 1982.

Foley, J. A., Ramankutty, N., Brauman, K. A., Cassidy, E. S., Gerber, J. S., Johnston, M., Mueller, N. D., O’Connell, C., Ray, D. K., West, P. C., Balzer, C., Bennett, E. M., Carpenter, S. R., Hill, J., Monfreda, C., Polasky, S., Rockström, J., Sheehan, J., Siebert, S., Tilman, D., and Zaks, D. P. M.: Solutions for a cultivated planet, Nature, 478, 337-342, https://doi.org/10.1038/nature10452, 2011.

Geerts, S., Raes, D., Garcia, M., Miranda, R., Cusicanqui, J. A., Taboada, C., Mendoza, J., Huanca, R., Mamani, A., Condori, O., and Mamani, J.: Simulating yield response of quinoa to water availability with AquaCrop, Agron. J., 101, 499-508, https://doi.org/10.2134/agronj2008.0137s, 2009. 
https://doi.org/10.5194/gmd-2021-98

Preprint. Discussion started: 17 May 2021

(c) Author(s) 2021. CC BY 4.0 License.

Han, C., Zhang, B., Chen, H., Liu, Y., and Wei, Z.: Novel approach of upscaling the FAO AquaCrop model into regional scale by using distributed crop parameters derived from remote sensing data, Agr. Water Manage., 240, 106288, https://doi.org/10.1016/j.agwat.2020.106288, 2020.

Gruber, A., De Lannoy, G., Albergel, C., Al-Yaari, A., Brocca, L., Calvet, J.-C., Colliander, A., Cosh, M., Crow, W., Dorigo, W., Draper, C., Hirschi, M., Kerr, Y., Konings, A., Lahoz, W., McColl, K., Montzka, C., Muñoz-Sabater, J., Peng, J., Reichle, R. M., Richaume, P., Rüdiger C., Scanlon T., van der Schalie R., Wigneron J.-P., and Wagner, W.: Validation practices for satellite soil moisture retrievals: What are (the) errors?, Remote Sens. Environ., 244, 111806, https://doi.org/10.1016/j.rse.2020.111806, 2020.

Hiederer, R.: Mapping Soil Properties for Europe - Spatial Representation of Soil Database Attributes, JRC Technical Report, EU publications, Luxembourg, 60 pp., https://doi.org/10.2788/94128, 2013.

Huang, J., Scherer, L., Lan, K., Chen, F., and Thorp, K. R.: Advancing the application of a model-independent open-source geospatial tool for national-scale spatiotemporal simulations, Environ. Modell. Softw., 119, 374-378, https://doi.org/10.1016/j.envsoft.2019.07.003, 2019.

Iizumi, T., Shin, Y., Kim, W., Kim, M., and Choi, J.: Global crop yield forecasting using seasonal climate information from a multi-model ensemble, Clim. Serv., 11, 13-23, https://doi.org/10.1016/j.cliser.2018.06.003, 2018.

Kopittke, P. M., Menzies, N. W., Wang, P., McKenna, B. A., and Lombi, E.: Soil and the intensification of agriculture for global food security, Environ. Int., 132, 105078, https://doi.org/10.1016/j.envint.2019.105078, 2019.

Liu, J., Williams, J. R., Zehnder, A. J., and Yang, H.: GEPIC-modelling wheat yield and crop water productivity with high resolution on a global scale, Agr. Syst., 94, 478-493, https://doi.org/10.1016/j.agsy.2006.11.019, 2007.

Lorite, I. J., García-Vila, M., Santos, C., Ruiz-Ramos, M., and Fereres, E.: AquaData and AquaGIS: two computer utilities for temporal and spatial simulations of water-limited yield with AquaCrop, Comput. Electron. Agr., 96, 227-237, https://doi.org/10.1016/j.compag.2013.05.010, 2013.

Maniruzzaman, M., Talukder, M. S. U., Khan, M. H., Biswas, J. C., and Nemes, A: Validation of the AquaCrop model for irrigated rice production under varied water regimes in Bangladesh, Agr. Water Manage., 159, 331-340, https://doi.org/10.1016/j.agwat.2015.06.022, 2015.

Mladenova, I. E., Bolten, J. D., Crow, W. T., Sazib, N., Cosh, M. H., Tucker, C. J., \& Reynolds, C.: Evaluating the operational application of SMAP for global agricultural drought monitoring. IEEE J. Sel. Top. in Appl., 12, 3387-3397, https://doi.org/10.1109/JSTARS.2019.2923555, 2019.

Monfreda, C., Ramankutty, N., and Foley, J. A.: Farming the planet: 2. Geographic distribution of crop areas, yields, physiological types, and net primary production in the year 2000, Global Biogeochem. Cy., 22, https://doi.org/10.1029/2007GB002947, 2008.

Monteith, J. L.: Solar radiation and productivity in tropical ecosystems, J. Appl. Ecol., 9, 747-766, https://doi.org/10.2307/2401901, 1972. 
https://doi.org/10.5194/gmd-2021-98

Preprint. Discussion started: 17 May 2021

(c) Author(s) 2021. CC BY 4.0 License.

(c) (i)

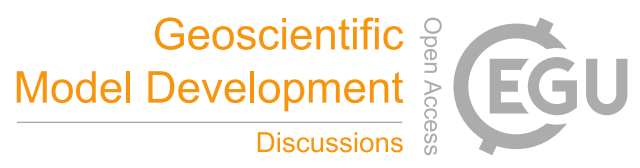

Müller, C., Elliott, J., Chryssanthacopoulos, J., Arneth, A., Balkovic, J., Ciais, P., Deryng, D., Folberth, C., Deryng, D., Folberth, C., Glotter, M., Hoek, S., Iizumi, T., Izaurralde, R. C., Jones, C., Khabarov, N., Lawrence, P., Liu, W., Olin, S., Pugh, A. M., Deepak, K. R., Reddy, A., Rosenzweig, C., Ruane, A. C., Sakurai, G., Schmid, E., Skalsky, R., Song, C. X., Wang, X., de Wit, A., and Yang, H.: Global gridded crop model evaluation: benchmarking, skills, deficiencies and implications, Geosci. Model Dev., 10, 1403-1422, https://doi.org/10.5194/gmd-10-1403-2017, 2017.

Müller, C., Elliott, J., Pugh, T. A., Ruane, A. C., Ciais, P., Balkovic, J., Deryng, D., Folberth, C., Izaurralde, R. C., Jones, C. D., Khabarov, N., Lawrence, P., Liu, W., Reddy, A. D., Schmid, E., and Wang, X.: Global patterns of crop yield stability under additional nutrient and water inputs, PloS one, 13, e0198748, https://doi.org/10.1371/journal.pone.0198748, 2018.

Nichols, J., Kang, S., Post, W., Wang, D., Bandaru, V., Manowitz, D., Zhang, X., and Izaurralde, R.: HPC-EPIC for high resolution simulations of environmental and sustainability assessment, Comput. Electron. Agr., 79, 112-115, https://doi.org/10.1016/j.compag.2011.08.012, 2011.

O'Neill, P. E., Chan, S., Njoku, E. G.,Jackson, T., Bindlish, R., and Chaubell, J.: SMAP Enhanced L2 Radiometer Half-Orbit 9 km EASE-Grid Soil Moisture- Version 4, NASA National Snow and Ice Data Center Distributed Active Archive Center, Boulder, Colorado, USA, https://doi.org/10.5067/Q8J8E3A89923, 2020.

Pingali, P. L.: Green revolution: impacts, limits, and the path ahead, P. Natl. Acad. Sci. USA, 109, 12302-12308, https://doi.org/10.1073/pnas.0912953109, 2012.

Raes, D., Geerts, S., Kipkorir, E., Wellens, J., and Sahli, A: Simulation of yield decline as a result of water stress with a robust soil water balance model, Agr. Water Manage., 81, 335-357, https://doi.org/10.1016/j.agwat.2005.04.006, 2006.

Raes, D., Steduto, P., Hsiao, T. C., and Fereres, E.: AquaCrop - the FAO crop model to simulate yield response to water: II. Main algorithms and software description, Agron. J., 101, 438-447, https://doi.org/10.2134/agronj2008.0140s, 2009.

Raes, D. and Vanuytrecht, E.: Food production and water: constraints and solutions for the future, Meded. Zitt. K. Acad. Overzeese Wet., 63, 265-288, https://doi.org/0.5281/zenodo.3894493, 2017.

Raes, D., Steduto, P., Hsiao, T. C., and Fereres, E.: AquaCrop version 6.0-6.1—chapter 3:calculation procedures, FAO of the UN, Rome, Italy, 25 pp, 2018.

Razzaghi, F., Zhou, Z., Andersen, M. N., and Plauborg, F.: Simulation of potato yield in temperate condition by the AquaCrop model, Agr. Water Manage., 191, 113-12, https://doi.org/10.1016/j.agwat.2017.06.008, 2017.

Resop, J. P., Fleisher, D. H., Wang, Q., Timlin, D. J., and Reddy, V. R.: Combining explanatory crop models with geospatial data for regional analyses of crop yield using field-scale modeling units, Comput. Electron. Agr., 89, 51-61, https://doi.org/10.1016/j.compag.2012.08.001, 2012.

Ritchie, J. T.: Model for predicting evaporation from a row crop with incomplete cover, Water Resour. Res., 8, 1204-1213, https://doi.org/10.1029/WR008i005p01204, 1972.

Roerink, G. J., Bojanowski, J. S., De Wit, A. J. W., Eerens, H., Supit, I., Leo, O., and Boogaard, H. L.: Evaluation of MSGderived global radiation estimates for application in a regional crop model, Agr. Forest Meteorol., 160, 36-47, https://doi.org/10.1016/j.agrformet.2012.02.006, 2012 . 
https://doi.org/10.5194/gmd-2021-98

Preprint. Discussion started: 17 May 2021

(C) Author(s) 2021. CC BY 4.0 License.

(c) (i)

Sallah, A. H. M., Tychon, B., Piccard, I., Gobin, A., Van Hoolst, R., Djaby, B., and Wellens, J.: Batch-processing of AquaCrop plug-in for rainfed maize using satellite derived Fractional Vegetation Cover data, Agr. Water Manage., 217, 346-355, https://doi.org/10.1016/j.agwat.2019.03.016, 2019.

515 Sandhu, R. and Irmak, S.: Performance of AquaCrop model in simulating maize growth, yield, and evapotranspiration under rainfed, limited and full irrigation, Agr. Water Manage., 223, 105687, https://doi.org/10.1016/j.agwat.2019.105687, 2019.

Siebert, S., Kummu, M., Porkka, M., Döll, P., Ramankutty, N., and Scanlon, B. R.: A global data set of the extent of irrigated land from 1900 to 2005, Hydrol. Earth Syst. Sc., 19, 1521-1545, 10.5194/hess-19-1521-2015, 2015.

Smets B., Swinnen E. and Van Hoolst R.: Copernicus Global Land Operations "Vegetation and Energy" “CGLOPS-1" product user manual: Dry Matter Productivity(DMP) - Gross Dry Matter Productivity (GDMP) - Collection 1 km - Version 2, CGLOPS-1 consortium, Brussels, Belgium, 47 pp, I322, 2019.

Steduto, P., Hsiao, T. C., Raes, D., and Fereres, E.: AquaCrop-The FAO crop model to simulate yield response to water: I. Concepts and underlying principles, Agron. J., 101, 426-437, https://doi.org/10.2134/agronj2008.0139s, 2009.

Still, C. J., Berry, J. A., Collatz, G. J., and DeFries, R. S.: Global distribution of C3 and C4 vegetation: carbon cycle implications, Global Biogeochem. Cy., 17, 6-1, https://doi.org/10.1029/2001GB001807, 2003.

Stöckle, C. O., Kemanian, A. R., Nelson, R. L., Adam, J. C., Sommer, R., and Carlson, B.: CropSyst model evolution: From field to regional to global scales and from research to decision support systems, Environ. Modell. Softw., 62, 361-369, https://doi.org/10.1016/j.envsoft.2014.09.006, 2014. 